\title{
Communicating Environmental Issue: Movie as Medium on Earth Conservation
}

\author{
Redi Panuju', Daniel Susilo² \\ \{redi.panuju@unitomo.ac.id ${ }^{1}$, daniel.susilo@unitomo.ac.id ${ }^{2}$ \} \\ ${ }^{1,2}$ Dr. Soetomo University, Indonesia
}

\begin{abstract}
This article would be describing the movie as Tools for communicating the environmental issue. Especially how to conserve on our mother-earth. This article will be focusing on movie "Bumiku" - My Earth, an Indonesian movie prepared by a teenager named Natasha Dematra and got recognition and prestigious award from International level. The narrative analysis will be used as the primary method to analyzing content on this Film. The result of this research, film as a good medium for communicating the environmental issue for teenager.
\end{abstract}

Keywords: environmental issue; movie; earth conservation.

\section{Introduction}

Etymologically, the term conservation comes from the English word, conservation, which means preservation or protection. Initially, the term conservation was used in Environmental science, which rests on the assumption that the human environment can be damaged by natural disasters, which can also occur due to human activity [1]. Human ambition to build a socioeconomic area by replacing the function of agricultural land into with houses, offices, industries, business centers, tourist centers, and others, has the potential to damage the surrounding ecosystem [2]. Natural balance can be disrupted due to damage to animal habitat, such as the loss of plants or forests that originally served as heat and water retention [3]. Furthermore, the ambition to build a modern region often changes ancient sites (historical heritage) that hold high artistic values.

Previous research on climate change, environmental conservation, and media can be traced from 1991 when Hansen started a discussion on the importance of media coverage on the environmental issue [4]. Pacoma, a scholar from the Philippines argue the urgent of awareness of Communication scholar on the environmental issue [5]. On his article, Pacoma shares the increasing number of media awareness on the Philippines about the environmental issue [5]. Another argument from Happer and Philo who found the coverage on media only focusing on human interest and tends on capitalism demand [6].

How about in Indonesia? Discussion engagement of Indonesian Communication Scholar or activist relative few compares with the Philippines. Yuliarti and Jatimurti frame how Indonesian media care about the plastic issue, and impact on readers [7]. Another view also presented by Susilo and Kodir who discussing relations of women and nature conservation as acts of struggling her motherland [8].

How important struggling our mother-earth in relations with media and conservation can be determined by how people aware of the importance of earth and environmental conservation. No second earth is the best reminder for people to educate no more choice, except change the habit now. 
Film and movies as mass media slightly effective medium in promoting the idea. On the research of Panuju and Susilo found how movies became an effective medium to promoting the idea of drinking alcoholic beverages [9]. Other research conduct by Murphy stated visual media are effective to gain awareness of people about the environmental issue [10].

\section{Methods}

Narrative analysis is analyzing narratives, both fictional narratives (poetry, folklore, fairy tales, films, etc.) or facts such as news. Narrative analysis means placing the text as a story (narration) according to the characteristics above. Text is seen as a series of events or parts of events selected and discarded [11].

From the above understanding, the movie can be analyzed through narrative analysis. Narrative analysis can fulfill the purpose of this research with its virtues. The integrity of narrative analysis, among others, explains in detail the character of the characters and events raised in the text. Clarify the position of the main character by determining between criminals and heroes. Explore ideas about environmental issues with a visible look.

Not all texts can be called narrative texts and analyzed through narrative analysis. The narrative that is intended has characteristics that are the basic requirements of a narrative. Eriyanto in his book "Narrative Analysis" classifies three characteristics, among others; first, there is a series of events. A narrative must have more than 2 events to say a narrative [11].

Second, sequences of events are not random, but according to a certain logic, the sequence can be tolerated because a narrative must be arranged according to certain logic so that it can show intent in the text.

Third, the narrative is not moving the event into the text, but there is always the selection and removal of certain parts. The editing and playing process of the sentence greatly dominates the making of the text to fulfill this requirement.

These three conditions must be applied in the text. Parts of this character can classify whether the text can be called narrative or not narrative. In other words, not all texts can be said as narratives and can be analyzed through narrative analysis.

The analysis technique adopted Tzevan Todorov, which focuses on three dimensions of the narrative, namely aspects of semantic (philosophy), verbal aspects (dialog) and aspects of the combination between the two [11], [12]. In this study, the aspects of philosophy are identified with the concepts made by Chaney \& Martin as objects behind the narrative. Chaney called it a backstage culture while the messages revealed through stories (scenes and dialogs) were called Frontstage culture. is the two are related to the purpose of the goal to embed cultural values or strengthen existing cultural values (enculturation) [13].

The main object in this research is Bumiku movie. Analysis unit for this research is a dialog, action, and text on the movie. This article discussed how film, as a mass media, is a means of enculturation of values that care about the environment and, at the same time, is a means of mobilizing actions that care for the environment. The film understudy is titled "Bumiku" (My Earth), created by Natasha Dematra.

\section{Results and Discussion}

Movie-makers insert messages through the dialog of the characters. In the "Bumiku", important dialogs represent the message to be conveyed. Important are presented in table 1. 
Table 1. Messages Through Dialog

\begin{tabular}{|c|c|c|}
\hline No & Dialog & Important Message \\
\hline 1 & $\begin{array}{l}\text { Adam: why do you like to dance? } \\
\text { Nada: Mama said, if we learn to dance, our } \\
\text { souls will be rich. We don't only need } \\
\text { knowledge, but also to be rich in the sense }\end{array}$ & $\begin{array}{l}\text { Life balance is formed from science } \\
\text { and sense }\end{array}$ \\
\hline 2 & $\begin{array}{l}\text { Dialog about teenagers who removed the } \\
\text { exhaust filter to be stylish. } \\
\text { Adam: crondolo kids } \\
\text { Nada: Those children just throw away fuel. } \\
\text { They only add smoke. We are getting hotter on } \\
\text { earth. } \\
\text { Adam: What do you mean? } \\
\text { Nada: Yes, the more the smoke generated, it } \\
\text { becomes useless for us and even more } \\
\text { harmful. }\end{array}$ & $\begin{array}{l}\text { The term Crondolo comes from the } \\
\text { Javanese language, which means } \\
\text { cricket children who do not have } \\
\text { wings. Used to say children who have } \\
\text { no ethics. Through music, children's } \\
\text { actions make heat on the earth. }\end{array}$ \\
\hline 3 & $\begin{array}{l}\text { Nada: The more fuel used, the more exhaust } \\
\text { gas produced. Later, the exhaust gas will be } \\
\text { trapped, gathered in the atmosphere. Some of } \\
\text { the sun's heat will be emitted, which will be } \\
\text { reflected again. However, because of the heat, } \\
\text { the sun can't be reflected again. The earth is } \\
\text { getting hotter. Well, this is what is meant by } \\
\text { global warming. If global warming occurs, the } \\
\text { climate will also change. Why are we, who } \\
\text { live on earth not trying to reduce the cause? } \\
\text { Adam: then? } \\
\text { Nada: Trees and plants are cut down. The trees } \\
\text { can turn exhausted gas into oxygen. As a } \\
\text { result, there will be many disasters such as } \\
\text { floods, crop failures and lack of clean water. }\end{array}$ & $\begin{array}{l}\text { Global warming is caused by exhaust } \\
\text { gases. The earth is getting hotter. Trees } \\
\text { and plants can turn exhausted gas into } \\
\text { oxygen; however, trees and plants are } \\
\text { being cut down a lot. Humans must be } \\
\text { aware to reduce this. }\end{array}$ \\
\hline 4 & $\begin{array}{l}\text { Nada Dialog with residents who are changing } \\
\text { lights: } \\
\text { Nada: changing lights, sir? } \\
\text { Penduduk: Yes, energy-saving lamps. To pay } \\
\text { for cheap electricity, as well as to prevent } \\
\text { climate change. Maintain the earth for } \\
\text { posterity. }\end{array}$ & $\begin{array}{l}\text { Prevent climate change for the future, } \\
\text { for posterity (next generation). }\end{array}$ \\
\hline 5 & $\begin{array}{l}\text { Mr. Heru's lecture to mothers who were taking } \\
\text { part in the training to recycle inorganic waste. } \\
\text { "Mothers, every day we recognize organic, } \\
\text { inorganic waste, plastic waste, bottle waste } \\
\text { and paper waste. Plastic waste can be recycled } \\
\text { into bags, sandals, vests, etc. }\end{array}$ & $\begin{array}{l}\text { Efforts to empower people to use waste } \\
\text { become something useful, while } \\
\text { reducing waste pollution. }\end{array}$ \\
\hline 6 & $\begin{array}{l}\text { Adam became dalang (story taller) through } \\
\text { Wayang Beber. } \\
\text { "This time, I will tell of a life related to natural } \\
\text { conditions. In Papua, in Kalimantan, in } \\
\text { Sumatra, trees have started to be cut down, } \\
\text { resulting in climate change and causing }\end{array}$ & $\begin{array}{l}\text { Wayang Beber Art can be a traditional } \\
\text { media for counseling about the } \\
\text { importance of preserving nature. }\end{array}$ \\
\hline
\end{tabular}




\begin{tabular}{|c|c|c|}
\hline $\mathrm{No}$ & Dialog & Important Message \\
\hline & $\begin{array}{l}\text { disasters everywhere. We have to plant crops } \\
\text { again, 'reforestation' and replacing energy- } \\
\text { saving lamps, sort out organic, inorganic, } \\
\text { bottle and paper waste and then discard them } \\
\text { separately" }\end{array}$ & \\
\hline 7 & $\begin{array}{l}\text { Nada Epilogue: "I have new experience and } \\
\text { knowledge. I have hope for the future of the } \\
\text { preservation of the earth. I want to preserve } \\
\text { the earth." }\end{array}$ & $\begin{array}{l}\text { Experience in the village fosters } \\
\text { enthusiasm, hope, and determination to } \\
\text { preserve the earth. }\end{array}$ \\
\hline
\end{tabular}

Sources: Primary data

The message through dialogs in table 2 corresponds to the statement of the Directorate General of Climate Development - the Ministry of Environment and Forestry as follows:

The United Nations Convention on the Climate Change Framework (United Nations Framework Convention on Climate Change / UNFCCC) defines climate change as something that is caused either directly or indirectly by human activities, thereby changing the composition of the global atmosphere and climate variability experience in comparable periods. The global atmospheric composition in question is the material composition of the Earth's atmosphere in the form of Greenhouse Gases (GHG), of which, it consists of Carbon Dioxide, Methane, Nitrogen and so on. Greenhouse Gases are needed to keep the temperature of the earth stable. However, increasing greenhouse gas concentrations make the atmosphere thicker. The thickening of the atmospheric layer causes the amount of geothermal energy trapped in the earth's atmosphere to increase, resulting in an increase in the earth's temperature, called global warming. (Knowledge Center for Climate Change, 2017)

\section{Conclusion}

Bumiku movie as a medium contains an effective message about the importance of environmental damage due to human activities unaware of the importance of environmental conservation. This movie was effective in increasing awareness of an environmental issue. Behaviors that cause environmental damage include deforestation, excessive use of electrical energy, disposal of gas from vehicles, use of plastic or inorganic goods and carelessly dumping them, which is a problem discussed by the film.

\section{Acknowledgments}

This research funding by DRPM Ministry of Research and the Higher Education Republic Indonesia with Grant Number: 005/SP2H/LT/K7/KM/2018

\section{References}

[1] M. Wikelski and S. J. Cooke, "Conservation physiology," Trends in Ecology and Evolution. 2006.

[2] S. Harrop, "Biodiversity and Conservation," in The Handbook of Global Climate and Environment Policy, 2013.

[3] M. A. Busari, S. S. Kukal, A. Kaur, R. Bhatt, and A. A. Dulazi, "Conservation tillage impacts on soil, crop and the environment," International Soil and Water Conservation 
Research. 2015.

[4] A. Hansen, "The media and the social construction of the environment," Media, Cult. Soc., 1991.

[5] M. A. Pacoma, "Environmental Realities: Evaluating Climate Change Coverage of Philippine Online News Media,” J. Stud. Komun. (Indonesian J. Commun. Stud., 2019.

[6] C. Happer and G. Philo, "The Role of the Media in the Construction of Public Belief and Social Change," J. Soc. Polit. Psychol., 2013.

[7] M. S. Yuliarti and W. Jatimurti, "Media and environment: how indonesia online news portal frames biodegradable issue?," J. Stud. Komun., vol. 3, no. 2, pp. 167-181, 2019.

[8] D. Susilo and A. Kodir, "Women's Leadership through the Context of Rembang Movement," in 2nd ICOCSPA Conference proceeding. Retrieved from: http://repository. unitomo. ac. id/992, 2016.

[9] R. Panuju and D. Susilo, "Alcoholic Beverages in Indonesian Movies," J. Drug Alcohol Res., 2019.

[10] T. P. Murphy, "The portrayal of the environment and development in two commercial movies," J. Environ. Educ., 1993.

[11] A. N. Eriyanto, "Dasar-dasar dan Penerapannya dalam Analisis Teks Berita Media," Jakarta Kencana Prenada Media Gr., 2013.

[12] À. Quintana, "Anchors in Time: Historic Memory and Representation," Hisp. Res. J., 2014.

[13] L. H. Chaney and J. S. Martin, Intercultural business communication. Boston: Pearson, 2014. 